\title{
Haptoglobin, serum amyloid $A$ and ceruloplasmin concentrations in cattle with suspicion of coryza gangrenosa bovum
}

\author{
Mustafa Issi ${ }^{1}$, Yusuf Gül ${ }^{1}$, Onur Başbuğ ${ }^{2 *}$, and Pinar A. Ulutaş ${ }^{3}$ \\ 'Department of Internal Medicine, Faculty of Veterinary Medicine, Firat University, Elazı̆̆, Turkey \\ ${ }^{2}$ Department of Internal Medicine, Faculty of Veterinary Medicine, Cumhuriyet University, Sivas, Turkey \\ ${ }^{3}$ Department of Biochemistry, Faculty of Veterinary Medicine, Adnan Mendres University, Aydin, Turkey
}

ISSI, M., Y. GÜL, O. BAŞBUĞ, P. A. ULUTAŞ: Haptoglobin, serum amyloid A and ceruloplasmin concentrations in cattle with suspicion of coryza gangrenosa bovum. Vet. arhiv 87, 703-712, 2017.

\section{ABSTRACT}

The aim of this study was to determine haptoglobin (Hp), serum amyloid-A (SAA) and ceruloplasmin (Cp) levels in naturally occurring cases of coryza gangrenosa bovum (CGB). The study was conducted on 14 animals, where 7 were sick cattle clinically diagnosed with CGB (patient group), and 7 healthy cattle from the same region (control group). It was determined that the general clinical examination results (rectal temperature, heart and respiratory frequency and rumen movement) detected in the patient group of animals showed significant differences $(\mathrm{P}<0.001)$ with respect to the animals in the control group. Serum Hp, SAA and $\mathrm{Cp}$ concentrations in the animals in the control group were determined as $0.22 \pm 0.02 \mathrm{mg} / \mathrm{mL}, 13.96 \pm 0.79 \mu \mathrm{g} / \mathrm{mL}$ and $8.10 \pm 2.85$ $\mathrm{mg} / \mathrm{dL}$ respectively, but $0.75 \pm 0.20 \mathrm{mg} / \mathrm{mL}, 182.25 \pm 22.63 \mu \mathrm{g} / \mathrm{mL}$ and $9.40 \pm 2.54 \mathrm{mg} / \mathrm{dL}$, respectively for the patient group. It was determined that $\mathrm{SAA}(\mathrm{P}<0.001)$ and $\mathrm{Hp}(\mathrm{P}<0.05)$ concentrations of the cattle in the patient group were significantly enhanced, while the increase in $\mathrm{Cp}$ levels were observed to be insignificant $(\mathrm{P}>0.05)$. Consequently, serum SAA and Hp concentrations in the cattle with CGB infection increased significantly in the acute phase of the disease, and it was concluded that further in-depth studies should be conducted on more animals in order to reveal the clinical significance of these changes in CGB infections, and also for precise diagnosis of CGB.

Key words: coryza gangrenosa bovum, haptoglobin, serum amyloid-A, ceruloplasmin

\section{Introduction}

Acute phase proteins (APPs) are mostly liver-derived and glycoprotein-structured blood proteins causing inflammation, tissue damage and infection in the organism, and having varying concentrations in neoplastic diseases (ECKERSALL and BELL, 2010;

\footnotetext{
${ }^{*}$ Corresponding author:

Assoc. Prof. Onur Başbuğ, PhD, Department of Internal Medicine, Faculty of Veterinary Medicine, Cumhuriyet University, 58140, Sivas, Turkey, Phone: +90 34621910 10; Fax: +90 34621911 10; E-mail: onurbasbug@hotmail.com
} 
M. Issi et al.: Haptoglobin, serum amyloid A and ceruloplasmin concentrations in cattle with suspicion of coryza gangrenosa bovum

ECKERSALL et al., 2006; HORADAGODA et al., 1999; PETERSEN et al., 2004). Those with lower concentration in the blood during the acute phase response are classified as negative APPs (retinol binding protein, albumin and transferrin) and those with enhanced concentration as positive APPs [haptoglobin (Hp), alfa acid glycoprotein, serum amyloid A (SAA), C-reactive protein, ceruloplasmin (Cp)] (GOKCE and BOZUKLUHAN, 2009).

Recently, although attention has been drawn to important fields of the use of APPs in veterinary surgery, no routine application has yet been used in veterinary clinics (CHAN et al., 2004; ECKERSALL, 2000; ECKERSALL and BELL, 2010; GOKCE and BOZUKLUHAN, 2009; SKINNER, 2001). However, the areas of use of APP measurements associated with the extend of tissue damage in affected animals and the severity of problem have increased over time (ECKERSALL and BELL 2010; SKINNER, 2001; ULUTAS et al., 2011). They may particularly be used in the early diagnosis and distinctive diagnosis of diseases, determination of prognosis, direction of treatments of diseased animals and determination of therapy efficiency, differentiation of viral and bacterial infections, distinction of clinic and sub-clinic diseases, identification of acute or chronic events, animal health screenings and control of herd health (ALSEMGEEST et al., 1994; ECKERSALL et al., 2006; GOKCE and BOZUKLUHAN, 2009; GRUYS et al., 1994; HORADAGODA et al., 1999; SKINNER, 2001; ULUTAS et al., 2011).

As blood concentrations and the diagnostic importance of APPs with clinical importance change in accordance with animal species, they should be evaluated separately for each animal species (ECKERSALL, 2000; ECKERSALL and BELL, 2010; ECKERSALL and CONNER, 1988; ECKERSALL et al., 2006; GOKCE and BOZUKLUHAN, 2009). The acute phase proteins enabling the best assessment of the health status of cattle are Hp (except for hemolytic cases), SAA and Cp (BASBUG and GUL, 2011; ECKERSALL and BELL, 2010; GRUYS et al., 1994; HORADAGODA et al., 1999; PETERSEN et al., 2004; SKINNER, 2001).

$\mathrm{Hp}$ is absent or barely exists $(<0.1 \mathrm{mg} / \mathrm{mL})$ in the blood serum of healthy cattle (AYTEKIN et al., 2016; BASBUG et al., 2016; ECKERSALL and CONNER, 1988; NAZIFI et al., 2009; SKINNER and ROBERTS, 1991). The serum concentration of SAA in healthy cattle is reported as $<24 \mu \mathrm{g} / \mathrm{mL}$ (GOKCE and BOZUKLUHAN, 2009; NAZIFI et al., 2009; ULUTAS et al., 2011). It was reported by HUSSEIN et al. (2012) that the serum Cp concentration reference values were between 8.8-33.4 mg/dL. In some studies, on the other hand, Cp levels were determined as $1.98 \mathrm{mg} / \mathrm{dL}$ by BASBUG et al. (2016), as 4.37 by AYTEKIN et al. (2016), as 5.6 by NISBET et al. (2008), as 6 by NAZIFI et al. (2009) and as 10.40 by AKALIN et al. (2015).

Increased levels of APPs found in infection conditions have been shown to change in accordance with the type, severity and course of infection in a variety of experimental and natural bacterial and viral diseases (AYTEKIN et al., 2016; BASBUG et al., 2016; 
M. Issi et al.: Haptoglobin, serum amyloid A and ceruloplasmin concentrations in cattle with suspicion of coryza gangrenosa bovum

ECKERSALL et al., 2006; GANHEIM et al., 2003; HOFNER et al., 1994; STENFELDT et al., 2011; ULUTAS et al., 2011).

In literature reviews, although there is a number of publications relating to serum $\mathrm{Hp}, \mathrm{SAA}$ and $\mathrm{Cp}$ concentrations in healthy cattle, it was determined that there is a limited number of studies relating to serum enzyme levels of APPs in viral infections (GANHEIM et al., 2003; HEEGARD et al., 2000; HOFNER et al., 1994; STENFELDT et al., 2011; ULUTAS et al., 2011). Within this scope, changes in APPs have been examined in bovine viral diarrhea virus (GANHEIM et al., 2003; ULUTAS et al., 2011), bovine respiratory syncytial virus (AYTEKIN et al., 2016), foot-and-mouth disease virus (HOFNER et al 1994; STENFELDT et al., 2011) and lumpy skin disease (BASBUG et al., 2016) infections. Nevertheless, in a number of studies the need is highlighted for a better understanding of the role of APPs and clinic areas of use (ECKERSALL and BELL, 2010; ULUTAS et al., 2011).

In literature reviews, no study was found in which serum $\mathrm{Hp}$, SAA and $\mathrm{Cp}$ concentrations were determined in cattle with CGB. Hence, the aim of this study was to determine Hp, SAA and $\mathrm{Cp}$ levels of important acute phase proteins for cattle in naturally occurring CGB cases.

\section{Materials and methods}

The study was conducted on a total of 14 animals of which 7 were naturally infected diseased cattle that had been clinically diagnosed as suffering from CGB (patient group), that had been brought to Firat University Veterinary Faculty Internal Diseases Clinic for examination and treatment, or had been directly examined on the spot in or around Elazı $\breve{g}$, and 7 healthy cattle (control group) provided from the same region.

The animals in the patient group according to their clinical findings were of different breeds (3 Holstein, 2 Brown Swiss, 2 Simmentals), ages (1-2 age) and genders (5 females, 2 males). Care was taken that the animals in the control group had similar features (animals with age interval of 1-2 years, 5 females, 2 males and 3 Holstein, 2 Brown Swiss and 2 Simmentals). Infectious bovine rhinotracheitis (IBR), mucosal disease and mastitis were not identified in either the control or the patient group. In order to prevent secondary infections of APPs in the patient group, subjects that were diagnosed as leucopenia in hematology and subjects that were in the acute phase were taken into the study first.

The history of the animals (kept in the same area with sheep) and clinical findings (anorexia, stomatitis, high fever, photophobia, lacrimation, keratitis) were evaluated in the diagnosis. In addition, the diagnosis was confirmed by looking at the central keratitis, which is considered to be pathognomonic in the diagnosis of CGB cattle.

After systematical clinical examination of all animals used in this study (ROSENBERGER, 1990), blood samples were taken into $10 \mathrm{~mL}$ sterile glass tubes from the vena jugularis in accordance with the procedure for assignment of $\mathrm{Hp}, \mathrm{SAA}$ and $\mathrm{Cp}$ 
M. Issi et al.: Haptoglobin, serum amyloid A and ceruloplasmin concentrations in cattle with suspicion of coryza gangrenosa bovum

levels, and serum was removed by 15 minutes of centrifuge at $3000 \mathrm{rpm}$ after 1 hour of incubation in a double boiler at $37{ }^{\circ} \mathrm{C}$. These were stored at $-20{ }^{\circ} \mathrm{C}$ until serum sample analyses were performed. Hp and SAA analyses were performed in accordance with the procedures using ELISA kits (Tridelta LTD, Ireland). The serum Cp concentration was measured by spectrophotometry (Schimatzu UV-1601, Japan) by the method reported by SUNDERMAN and NOMOTO (1970).

In analyses of all data obtained from the study, the $t$-test was applied using the SPSS MS Windows Release 21.0 computer program.

\section{Results}

It was learnt that the all the animals in the patient group had been inappetent and weak approximately 4-7 days before the anamnesis was taken, and excessive saliva, nasal draining and weight loss were also observed.

Table 1. Mean values of clinical examination results in cattle in the patient group, in the control group, and intergroup statistical differences

\begin{tabular}{|l|c|c|c|}
\hline Clinical findings & $\begin{array}{c}\text { Control group } \\
(\mathrm{X} \pm \mathrm{Sx}),(\mathrm{n}=7)\end{array}$ & $\begin{array}{c}\text { Patient group } \\
(\mathrm{X} \pm \mathrm{Sx}),(\mathrm{n}=7)\end{array}$ & $\mathrm{P}$ \\
\hline Rectal temperature $\left({ }^{\circ} \mathrm{C}\right)$ & $38.67 \pm 0.07$ & $39.98 \pm 0.13$ & 0.001 \\
\hline Heart frequency $(/ \mathrm{min})$. & $70.85 \pm 3.02$ & $88.00 \pm 3.26$ & 0.001 \\
\hline Respiratory frequency $(/ \mathrm{min})$. & $24.00 \pm 2.30$ & $38.28 \pm 2.13$ & 0.001 \\
\hline Rumen movements $(/ 5 \mathrm{~min})$. & $9.57 \pm 0.53$ & $4.00 \pm 0.81$ & 0.001 \\
\hline
\end{tabular}

The arithmetical means of clinical examination results (rectal temperature, rumen movements with heart and respiratory frequency) of the animals in the control and the patient groups, and the statistical importance of intergroup differences are given in Table 1. The arithmetical means of serum Hp, SAA and Cp levels of the animals in the control and the patient groups included in the study, and the level of intergroup statistical significance are summarized in Table 2.

Table 2. Arithmetical mean values of haptoglobin, serum amyloid-A and ceruloplasmin values in the cattle in the patient group, in the control group and intergroup statistical differences

\begin{tabular}{|l|c|c|c|}
\hline Parametre & $\begin{array}{c}\text { Control group } \\
(\mathrm{X} \pm \mathrm{Sx}),(\mathrm{n}=7)\end{array}$ & $\begin{array}{c}\text { Patient group } \\
(\mathrm{X} \pm \mathrm{Sx}),(\mathrm{n}=7)\end{array}$ & $\mathrm{P}$ \\
\hline $\mathrm{Hp}(\mathrm{mg} / \mathrm{mL})$ & $0.22 \pm 0.02$ & $0.75 \pm 0.20$ & $0.03^{*}$ \\
\hline $\mathrm{SAA}(\mu \mathrm{g} / \mathrm{mL})$ & $13.96 \pm 0.79$ & $182.25 \pm 22.63$ & $0.00^{* *}$ \\
\hline $\mathrm{Cp}(\mathrm{mg} / \mathrm{dL})$ & $8.10 \pm 2.85$ & $9.40 \pm 2.54$ & $0.74^{-}$ \\
\hline
\end{tabular}

${ }^{-} \mathrm{P}>0.05, *<0.05, * * \mathrm{P}<0.001$ 
At the end of the clinical examination, it was seen in all cases in the patient group that rectal temperature and heart and respiratory frequencies were increased, rumen movements were decreased, photophobia, lacrimation, conjunctivitis and formation of keratitis advancing from the periphery towards the center in both eyes were seen. Constipation was found in some cases ( 2 cases), and severe diarrhea in others ( 5 cases). In some cases, growth was seen of superficial lymph nodules ( 3 cases) and partial erosions were seen in the mouths of all patients.

It was determined that the general clinical examination results detected in the patient group animals showed significant differences $(\mathrm{P}<0.001)$ with respect to the control group of animals.

While SAA and Hp concentrations in the cattle in the patient group were found to be significantly higher with respect to the control group $(\mathrm{P}<0.001$ and $\mathrm{P}<0.05$, respectively), the increase in $\mathrm{Cp}$ levels was observed to be statistically insignificant $(\mathrm{P}>0.05)$.

\section{Discussion}

Coryza gangrenosa bovum is a viral disease seen in regions with both sheep and cattle farming, which causes important economic losses with mostly a sporadic course in cattle. The disease factor is a lymphotropic gamma herpesvirus. The virus has two strains, Alcelaphine herpesvirus-1 and Sheep associated herpesvirus. Sheep associated herpesvirus causes the disease in many countries, including Turkey. Having an incubation period of generally 2-8 weeks (it can last for up to 10 months in some instances), the disease has low morbidity and high mortality (GUL, 2016; RADOSTITS et al., 2008; ROSENBERGER, 1994).

From the literature (GUL, 2016; ISSI and GUL, 2001; RADOSTITS et al., 2008; ROSENBERGER, 1994) we found that the disease may be seen in cattle of all ages and breeds, and particularly pure bred young cattle are more sensitive; thusly, all the animals in the patient group were young pure-bred cattle.

It was determined in the cattle in the control group that clinical examination findings (SUNDERMAN and NOMOTO, 1970) and APP concentrations (AYTEKIN et al., 2016; BASBUG et al., 2016; ECKERSALL and CONNER, 1988; HUSSEIN et al., 2012; NAZIFI et al., 2009; NISBET et al., 2008; SKINNER and ROBERTS., 1991; ULUTAS et al., 2011) were within the indicated physiological limits.

As seen in Table 1, significant $(\mathrm{P}<0.001)$ differences were detected between the mean clinical parameters of cattle in the patient group and the values of the control. All these parameter changes show similarity with the literature (GUL, 2016; ISSI and GUL, 2001; ROSENBERGER, 1990). 
M. Issi et al.: Haptoglobin, serum amyloid A and ceruloplasmin concentrations in cattle with suspicion of coryza gangrenosa bovum

The fact that the clinical signficance of APPs varies from species to species was shown and it was indicated that this should be considered in evaluation of APPs. Particularly $\mathrm{Hp}$, SAA and Cp are regarded as important APPs as these are produced in low-levels in healthy cattle, but in extremely high concentrations during an acute phase response (BASBUG et al., 2011; GOKCE and BOZUKLUHAN, 2009; GRUYS et al., 1994; REGESSA and NOAKES, 1999; SKINNER, 2001; WALKER et al., 1994). Thus, these parameters were also determined in the study.

In this study, serum Hp, SAA and Cp concentrations were determined in the animals in the control group (Table 2) while these values were seen to be within the scope of the limits indicated for healthy cattle by other researchers (AKALIN et al., 2015; AYTEKIN et al., 2016; BASBUG et al., 2016; CHAN et al., 2004; ECKERSALL and CONNER, 1988; HUSSEIN et al., 2012; NAZIFI et al., 2009; NISBET et al., 2008; SKINNER, 2001; ULUTAS et al., 2011).

Detection of serum concentrations of APPs was suggested as a reliable indicator of the severity and precise definition of pathological events in humans and animals (SKINNER, 2001; ULUTAS et al., 2011).

In a study conducted on infectious and healthy cattle, SKINNER (2001) reported that $\mathrm{Hp}$ concentration in infectious diseases is higher than others. Some researchers (BASBUG et al., 2016; ULUTAS et al., 2011) speculated that in inflammatory diseases, Hp may increase by up to $200-300 \%$ and SAA may increase by up to $1000 \%$.

In the studies conducted, it was revealed that SAA and Hp values were extremely important markers (HORADAGODA et al., 1999) in distinctive diagnosis of bacterial (AYTEKIN et al., 2016; ECKERSALL et al., 2006; GANHEIM et al., 2003; SKINNER and ROBERTS, 1991; WALKER et al., 1994) and viral (BASBUG et al., 2016; GANHEIM et al., 2003; HEEGARD et al., 2000; HOFNER et al., 1994; STENFELDT et al., 2011; ULUTAS et al., 2011) diseases, and plasma levels in these diseases increased significantly.

In a study conducted by HOFNER et al. (1994) on cattle with foot-and-mouth disease, significant increases were detected in serum Hp levels in the period of appearance of clinical symptoms after the viremia stage of the disease. STENFELDT et al. (2011) stated that SAA and Hp increases may be used as a marker of acute infection in cattle with foot-and-mouth disease. In bovine respiratory syncytial virus caused experimentally by HEEGARD et al. (2000), it was indicated that Hp levels increased with the severity of the disease, SAA was the acute phase protein responding more rapidly to the infection, having higher sensitivity than Hp. GODSON et al. (1996) stated that body temperature increase, disease score and weight loss in herpesvirus type-1 / P haemolytica infection showed positive correlation with Hp levels, and the highest Hp levels were observed on the 8th day with occurrence of death. ULUTAŞ et al. (2011) reported that significant increases were seen in $\mathrm{Hp}$ and SAA levels in cattle persistently infected with Bovine viral diarrhea virus, and these increases were possibly associated with IL-6 and IL-8 
levels in positive acute phase proteins. It was stated by BASBUG et al (2016) that serum $\mathrm{Hp}$ and SAA concentrations increased significantly $(\mathrm{P}<0.001)$ in cattle with lumpy skin disease. Also, an important correlation was detected between the clinical appearance of the disease and Hp and SAA.

AKALIN et al. (2015) reported that Cp levels decreased in dairy cattle infected with bovine leukemia virus and this affected $\mathrm{Cp}$ synthesis of bovine leukemia virus, or it might suppress $\mathrm{Cp}$ secretion in the liver due to an unknown mechanism.

As may be seen in Table 2, serum Hp, SAA and Cp concentrations in diseased animals were determined. Hp $(\mathrm{P}<0.05)$ and SAA $(\mathrm{P}<0.001)$ concentrations in the cattle in the patient group were found to have increased significantly with respect to the control group, while the increase in $\mathrm{Cp}$ levels was observed to be statistically insignificant $(\mathrm{P}>0.05)$. These significant increases in serum Hp and SAA concentrations suggest that mediators secreted from the regions with tissue damage constitute an acute response (STENFELDT et al., 2011). In this study, increase in Hp and SAA levels in acute CGB conditions is compatible with the literature (HEEGARD et al., 2000; HOFNER et al., 1994; NISBET et al., 2008; STENFELDT et al., 2011).

In assessment of acute inflammation, SAA value is considered as a more sensitive indicator with respect to Hp and Cp values (BASBUG et al., 2016; HORADAGODA et al., 1999; NAZIFI et al., 2009). In this study, the fact that the difference between the SAA values in the control group cattle and the experimental group cattle was at the level of $\mathrm{P}<0.001$ supports these studies.

SAA and Hp levels from the acute phase proteins may exhibit significant changes during acute and chronical infections as an indication of inflammation (ALSEMGEEST et al., 1994; HORADAGODA et al., 1999; ULUTAS et al., 2011). In this study conducted by HORADAGODA et al. (1999) stated that the combination of Hp and SAA was a marker for the distinctive determination of acute and chronical inflammations. In the same study (HORADAGODA et al., 1999), the increase in Hp concentration in animals in the acute period was determined as $67 \%$ and in animals in the chronic period as $24 \%$. Thus, the usability of acute phase proteins in determining whether the disease is acute or chronic and particularly in differentiation of SAA and $\mathrm{Hp}$ was revealed as an important parameter. In a study conducted on healthy and diseased cattle by ALSEMGEEST et al. (1994), Hp and SAA values were found to increase markedly in diseased animals; thus, they may be used for distinctive diagnosis of acute and chronical diseases, using the calculated Hp/SAA ratio. It was stated that this ratio might also be useful in differentiation of subacute and chronic inflammatory diseases. In another study conducted by SKINNER and ROBERTS (1991), it was stated that severe acute infection was observed when Hp concentration was $>0.4 \mathrm{mg} / \mathrm{mL}$. 
M. Issi et al.: Haptoglobin, serum amyloid A and ceruloplasmin concentrations in cattle with suspicion of coryza gangrenosa bovum

The fact that the increase in Hp concentration was approximately $340 \%$ and that mean Hp levels in the patient group were $0.75 \mathrm{mg} / \mathrm{mL}$ is consistent with the literature (ALSEMGEEST et al., 1994; HORADAGODA et al., 1999; SKINNER and ROBERTS, 1991). An increase in Cp blood plasma levels up to $50 \%$ was reported after infection, trauma or inflammation (GRUYS et al., 1994).

In conclusion, it was determined that serum Hp and SAA concentrations increased significantly in the acute phase of the disease in cattle with CGB infection, and it was concluded that further in-depth studies should be conducted on more animals in order to reveal the clinical significance of these changes in CGB infections, and also for the precision of diagnosis of CGB.

\section{References}

AKALIN, P. P., V. S. ATASEVEN, F. DOGAN, Y. ERGUN, N. BASPINAR, O. OZCAN (2015): Selected biochemical and oxidative stres parameters and ceruloplasmin as acute phase protein associated with bovine leukemia virus infection in dairy cows. Bull Vet. Inst. Pulawy. 59, 327-330.

ALSEMGEEST, S. P., H. C. KALSBEEK, T. WENSING, J. P. KOEMAN., A. M. VAN EDEREN, E. GRUYS (1994): Concentrations of serum amyloid-A (SAA) and haptoglobin (HP) as parameters of inflamatory diseases in cattle. Vet. Q. 16, 21-23.

AYTEKIN, I., F. KAYA, H. ATALAY (2016): Evaluation of serum haptoglobin, caeruloplasmin and pseudocholinesterase levels in cows with botulism. Kafkas Univ. Vet. Fak. Derg. 22, 367-371.

BASBUG, O., Y. GUL (2011): Investigations on hemolysis in cows with tropical theileriosis. Kafkas Univ. Vet. Fak. Derg. 17, 421-427.

BASBUG, O., Z. T. AGAOGLU, N. TUZCU, A. COSKUN, U. AYDOGDU, A. YIGIN (2016): Tumor necrosis factor-alpha, hatoglobin, serum amyloid A and neopterin levels in cattle with lumpy skin disease. Kafkas Univ. Vet. Fak. Derg. 22, 411-418.

CHAN, J. P., C. C. CHU, H. P. FUNG, S. T. CHUANG, Y. C. LIN, R. M. CHU, S. L. LEE (2004): Serum haptoglobin concentration in cattle. J. Vet. Med. Sci. 66, 43-46.

ECKERSALL, P. D (2000): Recent advances and future prospects for the use of acute phase proteins as markers of diseases in animals. Revue Med. Vet. 151, 577-584.

ECKERSALl, P. D., F. J. YOUNG, A. M. NOLAN, C. KNIGHT, H. C. McCOMB, M. M. WATERSTON, C. J. HOGARTH, E. M. SCOTT, J. L. FITZPATRICK (2006): Acute phase proteins in bovine milk in an experimental model of Staphylococcus aureus subclinical mastitis. J. Dairy Sci. 89, 1488-1501.

ECKERSALL, P. D., J. G. CONNER (1988): Bovine and canine acute phase proteins. Vet. Res. Commun. 12, 169-178.

ECKERSALL, P. D., R. BELL (2010): Acute phase proteins: biomarkers of infection and inflamation in veterinary medicine. Vet. J. 185, 23-27. 
M. Issi et al.: Haptoglobin, serum amyloid A and ceruloplasmin concentrations in cattle with suspicion of coryza gangrenosa bovum

GANHEIM, C., C. HULTEN, U. CARLSSON, H. KINDAHL, R. NISKANEN, K. P. WALLER (2003): The acute phase response in calves experimentally infected with bovine viral diarrhoea virus and/or Mannheimia haemolytica. J. Vet. Med. B Infect. Dis. Vet. Public Health. 50, 183190.

GODSON, D. L., M. CANPOS, S. K. ATTAH-POKU (1996): Serum haptoglobin as an indicator of the acute phase response in bovine respiratory disease. Vet. Immunol. Immunopathol. 51, 292-299.

GOKCE, H. I., K. BOZUKLUHAN (2009): Important acute phase proteins in farm animals and their usage in veterinary practice. Dicle Üniv. Vet. Fak. Derg. 1, 1-14.

GRUYS, E., M. J. OBWOLO, M. TOUSSAINT (1994): Diagnostic significance of the major acute phase proteins in veterinary clinical chemistry: a review. Vet. Bull. 64, 1009-1018.

GUL, Y. (2016): Infectious diseases. In: Internal Medicine of Ruminants (Cattle, Sheep-Goats). (Gul, Y., Ed.), $4^{\text {nd }}$ ed., Medipres, Malatya, pp. 151-203.

HEEGARD, P. M. H., D. L. GODSON, M. J. M. TOUSSAINT (2000): The acute phase response of serum amyloid A in cattle undergoing experimental infection with bovine respiratory syncytial virus. Vet. Immunol. Immunopathol. 77, 151-159.

HOFNER, M. C., M. W. FOSBERY, P. D. ECKERSALL, A. I. DONALDSON (1994): Haptoglobin response of cattle infected with foot-and-mouth disease virus. Res. Vet. Sci. 57, 125-128.

HORADAGODA, N. U., K. M. G. KNOX, H. A. GIBBS (1999): Acute phase proteins in cattle: distrimination between acute and chronic inflamation. Vet. Rec. 17, 437-441.

HUSSEIN, H. A., R. STAUFENBIEL, A. E. MULLER, A. EL-SEBAIE, M. ABD-EL-SALAM (2012): Ceruloplasmin activity in holstein dairy cows: effects of lactation stages and anticoagulants. Comp. Clin. Pathol. 21, 705-710.

ISSI, M., Y. GUL (2001): Investigations on serum vitamin C levels in some infectious diseases of cattles. Firat University Veterinary Journal of Health Sciences, 15, 113-120.

NAZIFI, S., S. M RAZAVI, Z. ESMAILNEJAD, H. GHEISARI (2009): Study on acute phase proteins (haptoglobin, serum amyloid A, fibrinogen, and ceruloplasmin) changes and their diagnostic values in bovine tropical theileriosis. Parasitol. Res. 105, 41-46.

NISBET, C., S. CENESIZ, M. ACICI, S. UMUR (2008): Determination of the serum malondialdehyde, ceruloplasmin, adenosine deaminase levels in cattle with Cystic echinococcosis. J. Fac. Vet. Med. Univ. Erciyes. 5, 1-4.

PETERSEN, H. H., J. P. NIELSEN, P. M. H. HEEGAARD (2004): Application of acute phase protein measurements in veterinary clinical chemistry. Vet. Res. 35, 163-187.

RADOSTITS, O. M., C. C. GAY, K. W. HINCHCLIFF, P. D.CONSTABLE (2008): Veterinary Medicine: Textbook of the Diseases of Cattle, Horses, Sheep, Pigs and Goats. $10^{\text {th }}$ ed., Saunders Elsevier, Edinburgh, London, New York, Oxford, Philadelphia, St Louis, Sydney, Toronto.

REGESSA, F., D. E. NOAKES (1999): Acute phase protein response of ewes and the release of PGFM in relation to uterine involution and the presence of intrauterine bacteria. Vet. Rec. 144, 502-509. 
M. Issi et al.: Haptoglobin, serum amyloid A and ceruloplasmin concentrations in cattle with suspicion of coryza gangrenosa bovum

ROSENBERGER, G. (1990): Die kliniche Untersuchungen des Rindes. 3. Auflage, Verlag Paul Parey.

ROSENBERGER, G. (1994): Krankheiten des Rindes. 3. Unverenderte Auflage, Blackwell Wissenschafts Verlag, Berlin.

SKINNER, J. G. (2001): International standardization of akute phase proteins. Vet. Clin. Pathol. $30,2-7$.

SKINNER, J. G., L. ROBERTS (1991): Haptoglobin as an indiator of infection in sheep. Vet. Rec. 134, 33-36.

STENFELDT, C., P. M. H. HEEGAARD, A. STOCKMARR, K. TJORNEHOJ, G. J. BELSHAM (2011): Analysis of the acute phase responses of serum amyloid A, haptoglobin and type 1 interferon in cattle experimentally infected with foot-and-mouth disease virus serotype O. Vet. Res. 42, 66-75.

SUNDERMAN, F. W., S. NOMOTO (1970): Measurement of human serum ceruloplasmin by its p-phenylenediamine oxidase activity. Clin. Chem. 16, 903-910.

ULUTAS, B., T. TAN, P. A. ULUTAS, G. BAYRAMLI (2011): Haptoglobin and serum amyloid A responses in cattle persistently infected with bovine viral diarrhea virus. Acta Scientiae Veterinariae 39, 973-978.

WALKER, J. L., C. R. CLARKE, B. A. LESSLEY, C. M. HAGUE (1994): Effect of Pasteurella haemolytica infection on $\alpha-1$ acid glikoprotein and albumin concentration in serum and subcutaneous tissue chamber fluid of calves. Res. Vet. Sci. 56, 158-163.

Received: 1 August 2016

Accepted: 30 November 2016

ISSI, M., Y. GÜL, O. BAŞBUĞ, P. A. ULUTAŞ: Koncentracije haptoglobina, serumskog amiloida $A$ i ceruloplazmina u goveda sa sumnjom na zaraznu koricu goveda. Vet. arhiv 87, 703-712, 2017.

\section{SAŽETAK}

Istraživanje je poduzeto s ciljem određivanja razine haptoglobina (Hp), serumskog amiloida A (SAA) i ceruloplazmina $(\mathrm{Cp})$ u goveda oboljelih od zarazne korice. Provedeno je na 14 životinja od kojih je sedam bilo s kliničkom slikom bolesti, a sedam kontrolnih iz istog područja kao i oboljele. Nalazi opće kliničke pretrage (mjerenje temperature, frekvencija bila i disanja te kontrakcije buraga) u skupini bolesnih životinja bile su signifikantno veće $(\mathrm{P}<0,001)$ nego u kontrolnoj skupini. Koncentracije serumskog Hp, SAA i Cp u kontrolnoj su skupini iznosile $0,22 \pm 0,02 \mathrm{mg} / \mathrm{mL}, 13,96 \pm 0,79 \mu \mathrm{g} / \mathrm{mL}$ i $8,10 \pm 2,85 \mathrm{mg} / \mathrm{dL}$ dok su u skupini bolesnih one bile za Hp $0,75 \pm 0,20 \mathrm{mg} / \mathrm{mL}$, za SAA $182,25 \pm 22,63 \mu \mathrm{g} / \mathrm{mL}$ te za Cp 9,40 $\pm 2,54 \mathrm{mg} / \mathrm{dL}$. Koncentracije SAA $(\mathrm{P}<0,001)$ i $\mathrm{Hp}(\mathrm{P}<0,05)$ u skupini bolesnih životinja bile su značajno veće dok povećanje razine Cp nije bilo statistički signifikantno $(\mathrm{P}>0,05)$. To govori da su koncentracije serumskog SAA i Hp u goveda sa sumnjom na zaraznu koricu bile značajno veće u akutnoj fazi bolesti. Potrebno je poduzeti daljnja istraživanja na većem broju životinja da bi se utvrdilo kliničko značenje spomenutih promjena kod zarazne korice goveda što bi također bilo od važnosti za postavljanje točne dijagnoze te bolesti.

Ključne riječi: zarazna korica goveda, haptoglobin, amiloid-A, ceruloplazmin, serum 